\title{
A Comparison of Residential Energy Demand Behaviour in Britain and Australia
}

\author{
Sven Hallin1, Thomas Weyman-Jones ${ }^{2}$ \\ ${ }^{1}$ School of Architecture, Building and Civil Engineering, Loughborough University, Leicestershire, UK \\ ${ }^{2}$ School of Business and Economics, Loughborough University, Loughborough, UK \\ Email: hallinsf@hotmail.co.uk, t.g.weyman-jones@lboro.ac.uk
}

How to cite this paper: Hallin, S. and Weyman-Jones, T. (2018) A Comparison of Residential Energy Demand Behaviour in Britain and Australia. Open Journal of Energy Efficiency, 7, 100-117. https://doi.org/10.4236/ojee.2018.74007

Received: October 7, 2018

Accepted: December 2, 2018

Published: December 5, 2018

Copyright ( 92018 by authors and Scientific Research Publishing Inc. This work is licensed under the Creative Commons Attribution International License (CC BY 4.0).

http://creativecommons.org/licenses/by/4.0/

(c) (i) Open Access

\begin{abstract}
This research highlights an interesting finding comparing energy use in the residential sector in the United Kingdom and Australia. Energy consumed per capita is largely similar, however the energy available is manifestly different. Australia is blessed with a greater abundance of energy than the United Kingdom. Particularly, in the main area of study in Australia, Victoria state, Brown coal is easy and cheap to access. It is therefore politically more difficult to argue that the population affords more expensive sustainable energy resources even though Australia is one of the countries that can readily produce this type of energy. Britain, however, is a net importer of energy. A large proportion of this energy is natural gas which is a fossil fuel, and therefore contributes to the negative effects of climate change. The findings of this research focus on what motivates residential users of energy to use energy more sustainably. It presents the conclusions of previous research as a backdrop, and reveals the complexity of occupant behaviour. Key drivers are financial incentives and the role of large organisations such as governments in influencing behaviour. This may take significant time.
\end{abstract}

\section{Keywords}

Energy Policy, Behavioural Economics, Australia UK Comparison, Sustainable Energy

\section{Introduction}

The purpose of this research is to explore residential energy use in two developed countries, the UK and Australia. Few studies have been done comparing motivation behind such energy use in these two countries. This research looks at the comparative energy use in both countries along with the motivational factors 
that create the demand for energy in the residential sector, particularly in terms of behavioural economics.

\section{Energy in the UK and Australia}

The UK and Australia have very different energy regimes. The UK is a net importer of energy [1] while Australia is blessed with a plethora of different energy sources. This research looks at the motivation of two case study groups, one in the UK and one in Australia, to change their energy use so that it is more efficient and sustainable. The purpose of looking at these two case study groups, both from developed countries, is to gain an understanding if there is any difference between the motivations behind using particular types of energy. Underlying these motivations may be political, economic and social factors. This section discusses the approaches of each country towards creating a more sustainable energy environment.

Since the 1980s, the UK has had a number of energy efficiency schemes (see Table 1) under successive governments, while Australia only made a serious commitment to improve the sustainability of their energy use in 2008 [2].

The Green Deal was the U.K.'s most recent experience of a direct residential energy incentive scheme, and this was started in January 2013 and ended in July 2015 when all future funding ceased.

With regard to Australia, around the time of the publication of the Stern review [3], John Sandeman [4] presented a critique of Australian energy policy. $\mathrm{He}$ explained that Australia's dependence on cheap coal for electricity generation (approximately $80 \%$ ), combined with no allowance for carbon emissions in its pricing, meant that Australia was level with the United States of America as top carbon dioxide emitters per capita. The dependence on other mining industry, which was $\mathrm{CO}_{2}$ intensive contributed to this. However, on a global scale Australian carbon dioxide emissions represented just $2 \%$ of the world's total, and this fact had been the driver behind the Federal Government of Australia's policy on fossil fuel emissions. Australia had up to that time refused to sign the Kyoto protocol and the government believed that implementing a carbon price would seriously damage the economy. Even so, the greater level of awareness of the impact of fossil fuels on climate change increased the pressure for legislation of action on carbon pricing, and the federal government support for "voluntary reductions" in emissions. Australia made a Kyoto protocol commitment in 2008 to limit carbon dioxide emissions to $108 \%$ of 1990 levels for the period 2008 to 2012. In a report by the Australian Department of Climate Change and Energy Efficiency in 2012 [2], projections forecast that Australia's emissions were likely to have averaged 575 million tonnes of carbon dioxide equivalent ( $\mathrm{Mt} \mathrm{CO}_{2}$-e) over the Kyoto period, which represents 105 per cent of the 1990 level, so improving on the target level. The report suggested that without a carbon pricing mechanism or the Carbon Farming Initiative (CFI), Australia's emissions were forecast to be $693 \mathrm{Mt} \mathrm{CO}_{2}$-e in 2020 and $786 \mathrm{Mt} \mathrm{CO}_{2}$-e in 2030. 
Table 1. Summary of UK energy efficiency schemes.

\begin{tabular}{|c|c|c|}
\hline Year & Energy Efficiency Scheme & Rationale \\
\hline 1989 & $\begin{array}{l}\text { Non Fossil Fuel } \\
\text { Obligation (NFFO) }\end{array}$ & To support nuclear power \\
\hline 1990 & $\begin{array}{l}\text { Non Fossil Fuel } \\
\text { Obligation (NFFO) }\end{array}$ & To additionally support renewable energy \\
\hline 2000 & $\begin{array}{l}\text { Climate Change } \\
\text { Programme }\end{array}$ & $\begin{array}{l}\text { To reduce greenhouse gas emissions to mitigate climate } \\
\text { change (including promoting better energy efficiency } \\
\text { in the domestic sector and improving the energy efficiency } \\
\text { requirements of the building regulations) }\end{array}$ \\
\hline 2001 & $\begin{array}{l}\text { Climate Change } \\
\text { Levy (CCL) }\end{array}$ & $\begin{array}{l}\text { To tax nondomestic intensive energy users in industry and } \\
\text { the public sector. (Renewable energy suppliers were exempt }\end{array}$ \\
\hline 2001 & $\begin{array}{l}\text { Climate Change } \\
\text { Agreement }\end{array}$ & $\begin{array}{l}\text { Intensive energy companies who accepted the Climate } \\
\text { Change Agreement, could get a discount on the CCL tax of } \\
80 \% \text {. }\end{array}$ \\
\hline 2002 & $\begin{array}{l}\text { The Renewables } \\
\text { Obligation Order }\end{array}$ & $\begin{array}{l}\text { Required electricity end suppliers to purchase a proportion } \\
\text { of their electricity energy supply from renewable } \\
\text { technologies, receiving tradable renewable obligation } \\
\text { certificates in return (ROC's). }\end{array}$ \\
\hline 2002 & $\begin{array}{l}\text { Energy Efficiency } \\
\text { Commitment (EEC) }\end{array}$ & $\begin{array}{l}\text { Required energy suppliers to achieve a target level of } \\
\text { energy savings over the time period to } 2005 \text {, via } \\
\text { facilitating implementation of domestic energy efficiency } \\
\text { improvements. }\end{array}$ \\
\hline 2005 & $\begin{array}{l}\text { Energy Efficiency } \\
\text { Commitment (EEC) }\end{array}$ & $\begin{array}{l}\text { A second phase of EEC was implemented between } 2005 \\
\text { and } 2008\end{array}$ \\
\hline 2005 & $\begin{array}{l}\text { European Union Emissions } \\
\text { Trading System (EU ETS) }\end{array}$ & $\begin{array}{l}\text { To comply with the Kyoto Protocol. Tradable permits } \\
\text { introduced and divided amongst firms in sectors covered by } \\
\text { the agreement. }\end{array}$ \\
\hline 2007 & $\begin{array}{l}\text { Code for } \\
\text { Sustainable Homes }\end{array}$ & $\begin{array}{l}\text { To establish minimum energy performance standards for } \\
\text { the construction of new houses. } 25 \% \text { energy improvement } \\
\text { required over } 2006 \text { building regulations. }\end{array}$ \\
\hline 2008 & Climate Change Act & $\begin{array}{l}\text { To set a legally binding target of an } 80 \% \text { reduction in } \\
\text { carbon emissions from } 1990 \text { levels by } 2050 \text {. Carbon } \\
\text { budgets set for five year periods by appointed Committee } \\
\text { on Climate Change. }\end{array}$ \\
\hline 2009 & $\begin{array}{l}\text { Low Carbon } \\
\text { Transition Plan }\end{array}$ & Set out policies to reduce emissions across key sectors. \\
\hline 2008 & $\begin{array}{l}\text { Carbon Emissions } \\
\text { Reduction Target (CERT) }\end{array}$ & $\begin{array}{l}\text { Replaced the Energy Efficiency Commitment. Greater } \\
\text { focus on increased domestic energy saving measures and } \\
\text { increased commitment to target fuel poverty. }\end{array}$ \\
\hline 2008 & $\begin{array}{l}\text { Renewable Transport } \\
\text { Fuel Obligation }\end{array}$ & $\begin{array}{l}\text { Requires a specific percentage of UK road fuel to be from } \\
\text { renewables. }\end{array}$ \\
\hline 2008 & $\begin{array}{l}\text { Energy performance } \\
\text { certificates (EPC's) }\end{array}$ & EPC's give an energy performance rating \\
\hline 2009 & $\begin{array}{l}\text { Community Energy } \\
\text { Saving Programme }\end{array}$ & $\begin{array}{l}\text { To address fuel poverty in the UK via energy suppliers } \\
\text { facilitating domestic energy efficiency improvements. }\end{array}$ \\
\hline 2010 & $\begin{array}{l}\text { Code for } \\
\text { Sustainable Homes }\end{array}$ & Code revised to improve energy efficiency \\
\hline
\end{tabular}




\begin{tabular}{|c|c|c|}
\hline \multicolumn{3}{|c|}{ Continued } \\
\hline 2010 & $\begin{array}{l}\text { Carbon Reduction } \\
\text { Commitment Energy } \\
\text { Efficiency Scheme }\end{array}$ & $\begin{array}{l}\text { A mandatory scheme to improve energy efficiency and cut } \\
\text { emissions in large public and private sector organisations }\end{array}$ \\
\hline 2010 & Feed in Tariffs & $\begin{array}{l}\text { A subsidy provided for electricity which is fed into the grid } \\
\text { by small-scale low carbon generation. }\end{array}$ \\
\hline 2010 & Energy Act (2010) & To provide funding for Carbon Capture and Storage (CCS) \\
\hline 2011 & $\begin{array}{l}\text { The Carbon Plan: } \\
\text { Delivering our } \\
\text { low carbon future }\end{array}$ & $\begin{array}{l}\text { Proposed a mechanism for reducing carbon emissions in } \\
\text { the government sector up to } 2020\end{array}$ \\
\hline 2012 & Green Investment Bank & $\begin{array}{l}\text { Capital funding for projects that will assist the transition to } \\
\text { low carbon growth. }\end{array}$ \\
\hline 2012 & Renewable Heat Incentive & $\begin{array}{l}\text { Support for renewable heat installations for the } \\
\text { non-domestic sector }\end{array}$ \\
\hline 2012 & Energy Bill, 2012 & Formally introduced the Green Deal \\
\hline 2013 & Renewable Heat Incentive & $\begin{array}{l}\text { Support for renewable heat installations for the domestic } \\
\text { sector }\end{array}$ \\
\hline 2013 & Smart Meter Rollout & $\begin{array}{l}\text { To install smart electricity and gas meters to every } \\
\text { household }\end{array}$ \\
\hline
\end{tabular}

In 2012 the Australian government signed up to phase 2 of the Kyoto protocol. An unconditional emissions target of a 5\% reduction on 2000 levels by 2020 was agreed upon. A carbon pricing mechanism was introduced on 1 July 2012, and with this instrument in place Australia's net emissions were expected to be limited to $537 \mathrm{Mt} \mathrm{CO}_{2}$-e in 2020, which represented $155 \mathrm{Mt} \mathrm{CO}_{2}$-e of abatement in 2020. The scheme required enterprises which emitted over 25,000 tonnes per year of $\mathrm{CO}_{2}$-e and which were not in the transport or agriculture sectors to purchase emissions permits, initially at $\$ 23$ per tonne of carbon emissions.

The pricing of carbon dioxide emissions formed part of a broader package called the Clean Energy Future Plan. This aimed to reduce greenhouse gas emissions by $5 \%$ below 2000 levels by 2020 and $80 \%$ below 2000 levels by 2050 . The scheme was managed by the Clean Energy Regulator, with the intention that industry and households could be compensated for increased costs by the revenue derived from the carbon pricing. Initially the price of a permit to emit one tonne of carbon was fixed at \$23 for the 2012-13 financial year, with unlimited permits being available from the Government. This fixed price rose to $\$ 24.15$ for 2013-14. The government announced that the scheme would transition to an emissions trading scheme in 2014-15, where available permits would be limited in line with a pollution cap.

However, in September 2013 in a federal election a Liberal Government replaced the incumbent Labour Government. One of the election pledges of the new government was their intention to scrap the carbon tax, and this was formally abolished on 1 July 2014 . While the commitment to reduce greenhouse gas emissions remains in place (i.e. by $5 \%$ below 2000 levels by 2020 and $80 \%$ 
below 2000 levels by 2050), the new government intends to do this through their Plan for a Cleaner Environment [5]. The emissions reductions target will be achieved through a Direct Action Plan, which is designed to efficiently and effectively source low cost emissions reductions and improve the Australian environment. The intention is to do this through an Emissions Reduction Fund. This fund operates alongside other existing programs which are already intended to reduce Australia's emissions growth. These other programs include the Renewable Energy Target and mandatory efficiency standards on appliances, equipment and buildings. In June 2015 the Abbott Government downgraded the renewable energy target from 41,000 GWh per year to 33,000 GWh. While Tony Abbott is no longer leader of the Liberal Party, it is still in power, currently led by Scott Morrison. However the government has not yet significantly changed energy policy.

Because of the federal nature of Australia, which is a vast country with energy segmented amongst the states and territories, there are still significant policy barriers which exist at the federal and state levels. For example, current policy inherently favours mature technologies which are perceived to have the lowest investment risk. Greater support for variable renewable technologies which might prove more efficient in reducing emissions is needed, particularly solar power and wind power [6].

In 2006 Victoria (where part of this study was undertaken) became the first state to have a renewable energy target of $10 \%$ by 2016 . In 2010 the target was increased to $25 \%$ by 2020 [7].

\section{Literature Review Focussing on Behavioural Economics}

\subsection{Integrating Analysis of Residential Efficiency Behaviour}

Wilson \& Dowlatabadi [8] reviewed models of individual decision-making with regard to domestic energy. From very diverse perspectives they try to develop a more integrated approach to the analysis of behaviour and its relationship to design in a residential energy context. From this collective viewpoint they assert that there is a gap between economic/technological potential and actual market behaviour. In other words people don't make full use of the potential to reduce energy use.

Table 2 outlines various decision-making approaches they have highlighted.

It can be seen there are many different models of decision-making and behaviour to consider. Decision-making can be broadly grouped into psychological and contextual domains. Psychological elements include values, attitudes and personal norms. Contextual elements include the available choices, economic incentives, social norms, technologies, and infrastructures.

Wilson \& Dowlatabadi contrast the research that centres on the individual as a decision maker with that which emphasises the social and technological construction of behaviour (i.e. behaviour as a group). Despite this there are lessons to be learned from each research tradition when considering interventions. The 
key influences on decision-making need to be identified within a particular context. Their research cites the relevance of all the decision-making models to some aspect of residential energy use. They acknowledge that it is a challenge to combine different models of behaviour, particularly social and economic. This is an argument for further research in this area, to define the extent with which different models of behaviour can be integrated.

Table 2. Comparison of disciplinary approaches to decision making in the context of residential energy use [8].

\begin{tabular}{|c|c|c|c|c|c|}
\hline $\begin{array}{l}\text { Main } \\
\text { Features }\end{array}$ & $\begin{array}{l}\text { Conventional } \\
\text { Economics }\end{array}$ & $\begin{array}{l}\text { Behavioural } \\
\text { Economics }\end{array}$ & $\begin{array}{l}\text { Technology } \\
\text { Diffusion }\end{array}$ & $\begin{array}{l}\text { Social } \\
\text { Psychology }\end{array}$ & Sociology \\
\hline Decision model & $\begin{array}{l}\text { Utility maximisation } \\
\text { based on fixed and } \\
\text { consistent preferences }\end{array}$ & $\begin{array}{l}\text { Widely varying } \\
\text { decision heuristics } \\
\text { and context-dependent } \\
\text { preferences }\end{array}$ & $\begin{array}{l}\text { Attitude-based } \\
\text { evaluation of } \\
\text { technologies and the } \\
\text { consequences of } \\
\text { adoption }\end{array}$ & $\begin{array}{l}\text { Interacting } \\
\text { psychological and } \\
\text { contextual variables }\end{array}$ & $\begin{array}{l}\text { Sociotechnical } \\
\text { construction of } \\
\text { demand }\end{array}$ \\
\hline Decision scale & Individual & Individual & Individual/social & Individual/social & Social \\
\hline $\begin{array}{l}\text { Main research } \\
\text { methods }\end{array}$ & $\begin{array}{l}\text { Quantitative } \\
\text { (observed behaviour) }\end{array}$ & $\begin{array}{l}\text { Quantitative } \\
\text { (controlled } \\
\text { experiments) }\end{array}$ & $\begin{array}{l}\text { Quantitative and } \\
\text { qualitative } \\
\text { (surveys, interviews, } \\
\text { observed behaviour) }\end{array}$ & $\begin{array}{l}\text { Quantitative and } \\
\text { qualitative } \\
\text { (surveys, interviews, } \\
\text { observed behaviour) }\end{array}$ & $\begin{array}{l}\text { Qualitative } \\
\text { (interviews, } \\
\text { observation) }\end{array}$ \\
\hline $\begin{array}{l}\text { Main dependent } \\
\text { variables }\end{array}$ & $\begin{array}{l}\text { Preferences between } \\
\text { decision outcomes }\end{array}$ & $\begin{array}{l}\text { Preferences between } \\
\text { decision outcomes }\end{array}$ & Rate of diffusion & $\begin{array}{l}\text { Self-reports of } \\
\text { behaviour and/or } \\
\text { energy use }\end{array}$ & $\begin{array}{l}\text { Observed are } \\
\text { self-reported } \\
\text { behaviour }\end{array}$ \\
\hline $\begin{array}{l}\text { Main independent } \\
\text { variables }\end{array}$ & $\begin{array}{l}\text { Costs and benefits of } \\
\text { outcomes and their } \\
\text { respective weightings }\end{array}$ & $\begin{array}{l}\text { Aspects of the decision } \\
\text { frame, context, and } \\
\text { elicitation method, as } \\
\text { well as outcomes }\end{array}$ & $\begin{array}{l}\text { Adopt a role in } \\
\text { social networks, } \\
\text { communication } \\
\text { channels, technology } \\
\text { attributes, and } \\
\text { leadership of } \\
\text { adopter }\end{array}$ & $\begin{array}{l}\text { Values, attitudes, } \\
\text { norms, } \\
\text { sociodemographics, } \\
\text { economic incentives, } \\
\text { skills, capabilities, } \\
\text { and resources }\end{array}$ & $\begin{array}{l}\text { Social, cultural } \\
\text { and technical } \\
\text { determinants of } \\
\text { energy demand } \\
\text { embedded in } \\
\text { routine behaviour }\end{array}$ \\
\hline $\begin{array}{l}\text { Empirical basis in } \\
\text { energy use }\end{array}$ & Extensive & Very little & Some & Extensive & Some \\
\hline $\begin{array}{l}\text { Implications for } \\
\text { interventions to reduce } \\
\text { residential energy use }\end{array}$ & $\begin{array}{l}\text { Provide information } \\
\text { about benefits and } \\
\text { incentives to improve } \\
\text { cost benefit ratio and } \\
\text { improve cognitive } \\
\text { capacity to assess net } \\
\text { benefits/utility }\end{array}$ & $\begin{array}{l}\text { Pay attention to } \\
\text { framing and reference } \\
\text { points for decisions, } \\
\text { influence, heuristic } \\
\text { selection by } \\
\text { emphasising } \\
\text { associations or emotive } \\
\text { attributes, controlled } \\
\text { choice sets and default } \\
\text { options }\end{array}$ & $\begin{array}{l}\text { Segments target } \\
\text { population, exploit } \\
\text { communications } \\
\text { channels through } \\
\text { social networks and } \\
\text { use change agents, } \\
\text { identify stage of } \\
\text { decision process and } \\
\text { target groups and use } \\
\text { appropriate change } \\
\text { mechanisms, ensure } \\
\text { desired technology. } \\
\text { Our behaviour has } \\
\text { key attributes }\end{array}$ & $\begin{array}{l}\text { Influence attitudes only } \\
\text { if external conditions } \\
\text { are weak, use multiple } \\
\text { interventions with due } \\
\text { attention to interaction } \\
\text { effects, identify and } \\
\text { target barriers, design } \\
\text { salient and personally } \\
\text { relevant information, } \\
\text { values provided } \\
\text { disposition for a long } \\
\text { term change }\end{array}$ & $\begin{array}{l}\text { Work towards } \\
\text { long-term } \\
\text { sociotechnical } \\
\text { regime change, } \\
\text { exploit opportunities } \\
\text { of transition, recognise } \\
\text { the social role of } \\
\text { routine are habitual } \\
\text { behaviour, manage } \\
\text { expectations }\end{array}$ \\
\hline $\begin{array}{l}\text { Timescales for } \\
\text { interventions }\end{array}$ & Short-term & Short-term & Short to medium term & Short to medium term & Long-term \\
\hline
\end{tabular}




\subsection{Irrationality in Human Behaviour and Market Failure}

A specialist on behavioural economics, a recurrent theme of Thaler [9], who is now a Nobel Lauriate, is that market-based approaches are imperfect. The assumption that individuals are highly rational and unemotional is unrealistic. Instead bias needs to be recognised as a factor when people make choices [10] and often these biases are predictable which makes the approach of behavioural analysis useful. Many routine biases can result in poor choices by people with regard to personal finance, their health, and how informed they are. Thaler argues that their choices can affect such nebulous concepts as their happiness and how they interact with the environment. In addition, Kahneman and Tversky's Prospect Theory [11] outlines an approach to consumer decision making under risk and uncertainty that has proved empirically more robust than the standard neoclassical economics approach based on optimal behaviour by rational risk averse consumers.

These ideas form the foundation of Thaler's work on Nudge Theory. The theory implies public and private organisations can help people make better choices in their daily lives. It endeavours to improve perception of heuristic thinking on human behaviour, i.e. the rules of thumb and shortcuts that people adopt when making estimates and forecasts in uncertain situations. These heuristic influences are central to decision-making in trying to determine choice. People have certain tendencies, and Nudge theory seeks to promote choices which encourage helpful, positive decision-making which ideally benefit the wider interests of society.

Table 3 outlines the variety of heuristics or thinking habits that consumers use in decision making, while the assumptions in Kahneman and Tversky's Prospect Theory [11] are set out below this table.

The assumptions in Kahneman and Tversky [11] Prospect Theory that distinguish them from standard neoclassical economics, which is based on expected utility theory, are:

- Changes to wealth are evaluated rather than the total wealth outcome to reflect reference dependence, i.e. the change embodied in the project relative to no project is all that is considered.

- The subjective value of wealth change is an increasing function of the positive outcome changes and a decreasing function of the negative outcome changes. However, the rate of decrease of subjective value for a negative change exceeds the rate of increase of subjective value for a positive change. This much higher subjective penalty on income or wealth loss as opposed to income or wealth gain is referred to as loss aversion. Advocates of prospect theory and behavioural economics in general believe that this contrast between the subjective value of losses and gains of equal but small arithmetic value is an observable reality. It contrasts with the assumption of risk aversion in expected utility theory where the critical factor is the variability of outcomes, but the change in subjective valuation is the same for both small-scale positive variability and small-scale negative variability. 
- Kahneman and Tversky's experimental evidence also demonstrated that consumers do not use objective probabilities of risky outcomes directly but subjectively adjust them so that they overestimate the likelihood of extreme losses compared with observed frequencies and underestimate the likelihood of larger gains.

The chief consequence of these empirical findings embodied in Prospect Theory is that consumers will reject investments, e.g. in energy saving, that they would be predicted to adopt using standard expected utility theory. Combined with the biases and heuristics adopted in estimation of uncertain outcomes outlined in Table 3, the result is that many consumer decisions appear irrational and in particular in the context of energy saving lead to low take up of sensible energy saving procedures. The purpose of nudge theory is to enable consumers to avoid faulty decision making of this kind but without coercion and by relying on the simplified presentation of options.

Table 3. Nudge Theory [10].

Heuristics in "nudge" theory overview

1. Anchoring and Using known facts and adjusting them to estimate or decide something adjustment which is unknown.

The more familiar something is, the more frequently, it is used/communicated.

2. Familiarity misplaced sense of trust may be developed in behaving in a particular way, as well as a belief that this behaviour is valid. This heuristic is influenced by advertising and mass media.

3. Similarity

People make heuristic assumptions on the basis of perceived similarities to stereotypes.

4. Over-optimism

People tend to under-estimate costs, timescales, and challenges, and to over-estimate rewards and the ease of dealing with unknown things.

The tendency for people to value possessions more than potential possessions - this creates inertia to making changes. Irrationally,

5. Loss aversion people do not like to lose possession of things, irrespective of their actual value/importance. (The assumptions in Kahneman and Tversky Prospect Theory are set out below this table).

6. Status quo bias People prefer the status quo and fear changing to the unknown. Status quo bias is also caused by heuristic aversion to complexity.

Framing is an individual's method of heuristically understanding reality. It can

7. Framing therefore include many ways of distorting the attractiveness/unattractiveness of something.

8. Temptation

Generally people are naturally biased towards preferring short-term rewards rather than long-term rewards.

9. Thoughtlessness Often people tend to form views and make decisions heuristically without concentrating. This can mean they can miss making important decisions.

10. Conforming People have the need for affirmation, and wish to avoid risk or embarrassment. with the population Cultural factors add to these effects.

12. Self spotlight People tend to over-estimate the significance of their own decisions and effect actions, and how others view them. This can influence decision-making.

13. Choice architecture

This major area overlaps several individual heuristics, and refers to the degree to which something is designed to help people understand and make the best response to it. For example, green usually means "go" and red means "stop". 
In a development of Thaler's work, Akerlof \& Kranton [12] argue that individuals do not have preferences only over different goods and services, but that they also adhere to a social norm which determines how different people should behave. These norms are linked to a person's social identity, a concept that first appeared in previous work by Akerlof \& Kranton [13]. For example, people form an identity that may fit with their subculture. People from some communities may tend not to finish their education, while others may see themselves as expected to conform to certain standards of behaviour, such as not taking pens home from work.

On an economy wide scale, Akerlof \& Shiller's [14] analysis of the interaction of human psychology between the group and the individual gives a more plausible account than classical economic theory of the cause and effect leading to the financial collapse in 2008. Their book invokes the phrase "animal spirits" which Keynes [15] employed to describe the emotional psychology that in some part explains why the economy doesn't behave in the manner predicted by classical economics.

Kahneman [16] in his work on cognitive bias, prospect theory and happiness contends that there are two modes by which humans think:

System 1, which is fast, instinctive and emotional.

System 2, which is slower, more deliberative, and more logical.

He postulates that we use both systems. System 1 is informed by natural drives and instincts, and relies on heuristics (mental shortcuts) which an individual will evolve over time. While system 1 is a kind of fast mechanism to avoid danger, it feeds its experience into the slower system 2 . While system 2 can take a logical view over positives and negatives in terms of decision-making, Kahneman contends that it is naturally very poor with probability and statistics (although it can be trained to improve in this respect). It is also poorly equipped to correct the errors fed through to it from system 1 . As such it is not a paragon of rationality.

There are cognitive biases associated with each type of thinking. One conclusion he makes is that we place too much confidence in human judgement. If this construct is accepted, one possible lesson might be to devise energy policy to appeal to heuristic norms. Additionally, incentives may need to be large enough to outweigh any doubts about the probability of their benefit. As Akerlof and Kahneman, amongst others have argued, behavioural factors have to some extent undermined the concept of utility in economics.

\section{Methodology}

\section{Summary Data Collection and Analysis}

All participants were chosen based on rationale which took into account the researcher's view that they had sufficient knowledge of energy use and climate change.

The process by which qualitative data was collected and analysed (both in the UK and Australia) was as follows: 
1) Key questions were drawn from the literature review.

2) Interview questions were drawn up designed to elicit the information needed to answer the key questions.

3) Interviews were conducted with participants using prepared interview questions, however, these were "open" questions as the research approach was inductive, rather than deductive. Interesting points made by the participants were followed up by further impromptu questions from the researcher.

4) Interviews were transcribed, and from the resultant text, inferential statements were associated with participants.

5) A frequency analysis was conducted in order to understand the degree to which participants' views were aligned with the inferential statements (these inferential statements generally, but not always, could be related to perspectives in the literature review).

6) Purposive sampling [17] (Bryman, 2008) was used to select the case study participants. All case study participants were treated anonymously with their names changed.

7) The geographical location of the research participants had no primary foundation other than practicality for the researcher. Further study of other regions or nationally may determine if geography is a factor influencing the study results. However, the study allows some account to be taken of gender and age.

8) Details of the case study participants are summarised in Table 4 and Table 5.

Table 4. UK case study participants.

\begin{tabular}{ccccc}
\hline Participant & Gender & Age Range & Occupation & Tenure \\
\hline Robert & Male & 18 to 29 & Research student & Owner \\
Gwen & Female & 18 to 29 & Research student & Tenant \\
Jane & Female & 30 to 40 & Research student & Tenant \\
Wendy & Female & 30 to 40 & Research student & Tenant \\
Anne & Female & 18 to 29 & Research student & Tenant \\
Arabella & Female & 30 to 40 & Research student & Tenant \\
Juliette & Female & 30 to 40 & Teacher & Owner
\end{tabular}

Table 5. Australian case study participants.

\begin{tabular}{|c|c|c|c|c|}
\hline Participant & Gender & Age Range & Occupation & Tenure \\
\hline Bruce & Male & 18 to 29 & Student & Tenant \\
\hline Sue & Female & 30 to 40 & Mother & Owner \\
\hline Angela & Female & 40 to 50 & $\begin{array}{c}\text { Research } \\
\text { practitioner }\end{array}$ & Owner \\
\hline Mandy & Female & 18 to 19 & Interior designer & Tenant \\
\hline Tilly & Female & $60+$ & Research fellow & Owner \\
\hline Ellie & Female & 50 to 60 & Librarian & Owner \\
\hline
\end{tabular}


A compelling reason to involve Australian participants in this research was the developing debate on energy policy in Australia. It is a country that is actively engaged in policy debate around climate change and the environmental need to enhance sustainable energy supply. The research in Australia was also supported by access to information from the Institute for Strategic Economic Studies at Victoria University and involved discussions with other researchers involved with the energy efficiency and climate change agenda. The Institute as a whole has a strong energy-environment agenda and has been addressing a wide range of policy issues, especially in relation to buildings. In addition, the political change involving the scrapping of the carbon tax meant that it was particularly interesting to gauge the case study participant's opinions on energy sustainability in the residential sector.

All UK participants study lived within relatively close proximity of Loughborough, East Midlands.

All of the participants involved in the Australian study lived within relatively close proximity of Melbourne, the capital of Victoria State.

A greater consideration of the methodology and sampling methods used in this research are available by reference to Hallin [18].

\section{Case Study Results}

\subsection{A Comparison of UK and Australian Case Studies}

As has been discussed in section 1 there have been a series of initiatives in the UK since 1989, which has consistently increased the pressure to use energy more sustainably and efficiently throughout all sectors of the economy. All the main political parties have broadly supported this development in energy policy. In the domestic sector, the Green Deal policy did not face any significant political opposition, despite its failure. In contrast, Australian energy policy is both fragmented and in a state of flux. Victoria State does not, so far, implement residential energy regulation as part of a national structure.

The Australian Department of Climate Change and Energy Efficiency [2] still confirm Australia as one of the top carbon dioxide emitters per capita. However, if the Australian carbon tax had remained in place, emissions were projected to drop by nearly half between 2012 and 2030. It is a matter of speculation as to what the effect of any eventual sustainable energy policy may be.

Figure 1 shows the breakdown in domestic energy use by energy type in Petajoules (PJ). A petajoule is a large unit of energy equivalent to one thousand million million joules of energy, or nearly 288 million kilowatt hours (KWh). 1 Megawatt hour $(\mathrm{MWh})=1000$ Kilowatt Hours (Kwh). 1 tonne of oil equivalent (Mtoe) $=11.63 \mathrm{MWh}$. So in Figure 1 then 288 million KWh is approximately 24,763 toe (or $1 \mathrm{PJ}$ ). $225 \mathrm{PJ}$ is around 5.5 Million tonnes of oil equivalent (Mtoe), the Australian electricity use and $150 \mathrm{PJ}$ is around 3.7 Mtoe, the Australian natural gas use. Total energy consumption is in the order of 10 Mtoe (in 2011).

The UK domestic sector breakdown is represented in Figure 2. 


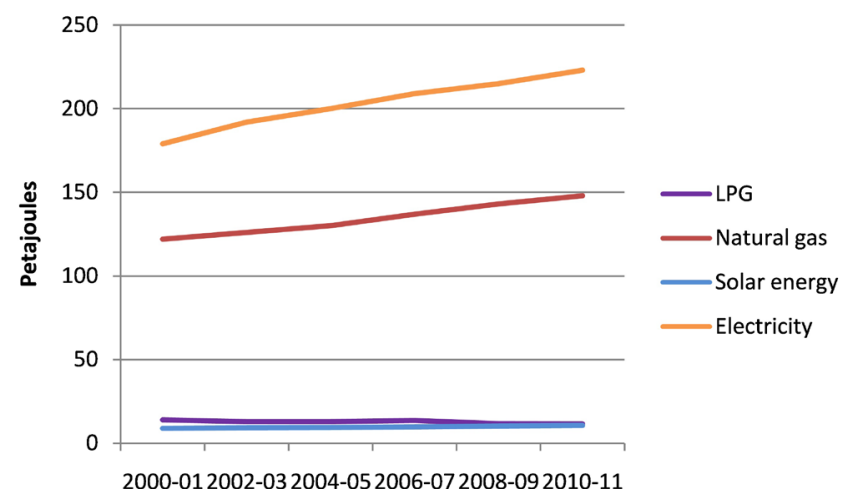

Figure 1. Australian Household Energy Consumption by fuel 2000-01-2010-11 [19]. Excludes fuels used for transport purposes. LPG is Liquefied petroleum gas (Adapted from BREE, 2012).

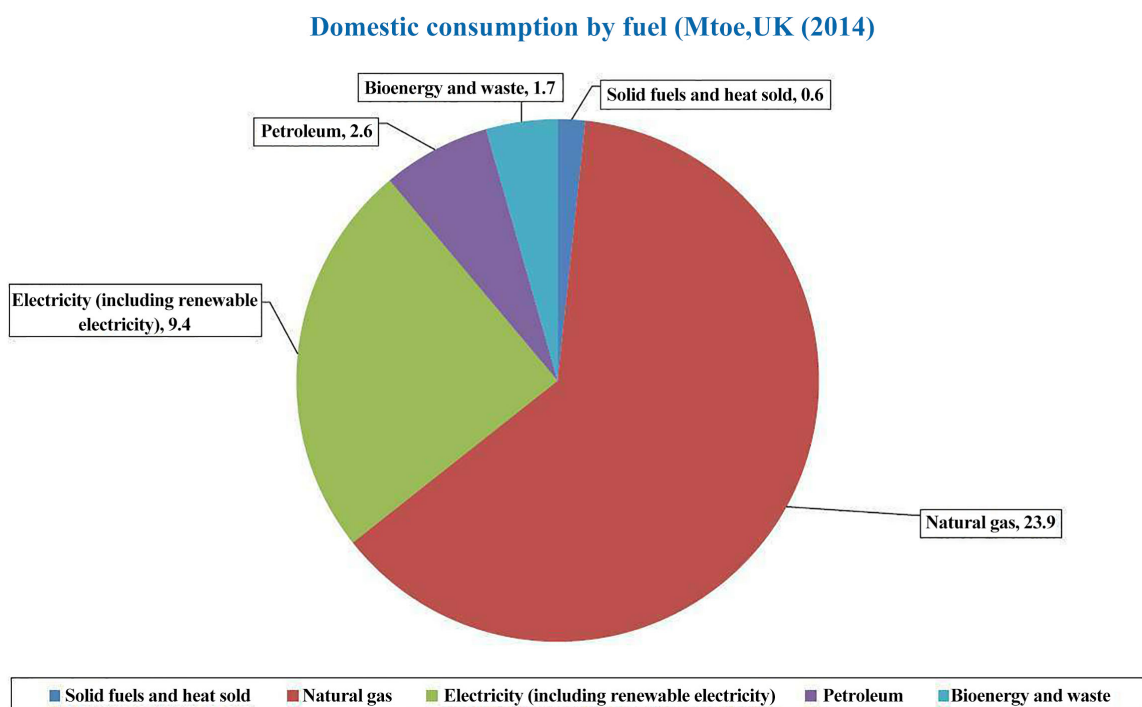

Figure 2. UK Household Energy Consumption by fuel UK 2014 [20].

In 2014, energy consumption from the UK domestic sector (excluding transport use) was 38.2 million tonnes of oil equivalent (Mtoe).

While exactly comparable figures were unavailable for this research, it would not be unreasonable to estimate total Australian domestic energy use in 2014 as approximately 11 Mtoe. This is for a population of approximately 22 million [21] and equates to 0.5 toe per capita. With UK domestic energy use at 38 Mtoe and a population estimate of 63 million [21], this equates to 0.6 toe per capita approximately. So, Australian domestic energy use could be said to be slightly less than in the UK. Electricity is however a far greater component of Australian domestic energy use, and a large proportion of this, around 90\%, is generated using fossil fuels, of which coal represents around 68\% [22]. This way of generating electricity is far less efficient than doing so using renewable energy or nuclear power, because much of the fossil fuel energy source gets wasted as heat in the generating process. In the UK, most domestic space heating relies on gas being pumped directly into the home before it is combusted to produce energy for 
heat. This is more efficient than a large power station burning gas to generate steam required by a turbine to produce electricity.

Table 6 shows a comparison of per capita energy consumption between the UK and Australia.

\subsection{Individual Viewpoints}

In both the UK and Australia, there was overlap between individual viewpoints (See Table 7 and Table 8). Jane (UK) has a strong ideological belief that energy should be used sustainably and efficiently. Sue (Aus) also has a strong ideological belief that she should control how she uses her energy, to the point where she is building her own house which is off grid i.e. generating her own power requirements from solar panels.

Table 6. Comparison of UK/AUS per capita energy consumption.

\begin{tabular}{cc}
\hline $\begin{array}{c}\text { Per capita UK/Australia Household Energy Consumption } \\
\text { in Million tonnes of oil equivalent (Mtoe) }\end{array}$ & 2014 \\
\hline UK & 0.6 Mtoe \\
Australia & 0.5 Mtoe \\
\hline
\end{tabular}

Table 7. UK participant responses.

\begin{tabular}{|c|c|c|c|c|}
\hline Inferred Statement & $\begin{array}{l}\text { Mixed } \\
\text { View }\end{array}$ & $\begin{array}{l}\text { Negative } \\
\text { view }\end{array}$ & $\begin{array}{l}\text { Positive } \\
\text { View }\end{array}$ & $\begin{array}{l}\text { Balance } \\
\text { of view }\end{array}$ \\
\hline Collective action is important & 4 & 0 & 2 & Uncertain \\
\hline $\begin{array}{l}\text { Useful if we could choose the energy } \\
\text { we get supplied to our home }\end{array}$ & 1 & 0 & 3 & Positive \\
\hline Education is the most important thing & 2 & 2 & 3 & Uncertain \\
\hline $\begin{array}{l}\text { People are influenced by the culture } \\
\text { around them }\end{array}$ & 1 & 3 & 3 & Uncertain \\
\hline What is your attitude to nuclear power & 3 & 1 & 3 & Uncertain \\
\hline Differential tariffs are a good idea & 2 & 1 & 4 & Uncertain \\
\hline Smart meters are useful & 4 & 0 & 3 & Uncertain \\
\hline People don't think that rationally & 0 & 0 & 7 & Positive \\
\hline $\begin{array}{l}\text { The government should } \\
\text { nudge us in the right direction }\end{array}$ & 1 & 0 & 4 & Positive \\
\hline $\begin{array}{l}\text { Government regulation is } \\
\text { important in residential energy use }\end{array}$ & 0 & 1 & 4 & Positive \\
\hline $\begin{array}{l}\text { What is your view on population } \\
\text { and energy (bad effects) }\end{array}$ & 2 & 4 & 1 & Negative \\
\hline $\begin{array}{l}\text { Financial situation is the } \\
\text { driver behind energy use }\end{array}$ & 1 & 1 & 3 & Positive \\
\hline What is your attitude to the Green Deal & 3 & 3 & 1 & Uncertain \\
\hline $\begin{array}{l}\text { How would you feel about being } \\
\text { given a personal carbon allowance }\end{array}$ & 3 & 1 & 3 & Uncertain \\
\hline $\begin{array}{l}\text { Would you be prepared to } \\
\text { pay a carbon tax }\end{array}$ & 3 & 2 & 2 & Uncertain \\
\hline
\end{tabular}


Table 8. Australian participant responses.

\begin{tabular}{|c|c|c|c|c|}
\hline $\begin{array}{l}\text { Inferred } \\
\text { Statement }\end{array}$ & $\begin{array}{l}\text { Mixed } \\
\text { View }\end{array}$ & $\begin{array}{l}\text { Negative } \\
\text { view }\end{array}$ & $\begin{array}{l}\text { Positive } \\
\text { View }\end{array}$ & $\begin{array}{l}\text { Balance } \\
\text { of view }\end{array}$ \\
\hline Collective action is important & 1 & 0 & 5 & Positive \\
\hline $\begin{array}{l}\text { Useful if we could choose the energy } \\
\text { we get supplied to our home }\end{array}$ & 2 & 0 & 4 & Uncertain \\
\hline $\begin{array}{l}\text { Education is the most important } \\
\text { thing }\end{array}$ & 3 & 0 & 2 & Uncertain \\
\hline $\begin{array}{l}\text { People are influenced by the culture } \\
\text { around them }\end{array}$ & 1 & 1 & 4 & Positive \\
\hline Attitude to nuclear power & 3 & 3 & 0 & Negative \\
\hline $\begin{array}{c}\text { Renewable energy could power } \\
\text { Australia }\end{array}$ & 2 & 1 & 3 & Uncertain \\
\hline Differential tariffs are a good idea & 3 & 0 & 3 & Uncertain \\
\hline Smart meters are useful & 3 & 0 & 3 & Uncertain \\
\hline People don't think that rationally & 1 & 0 & 4 & Positive \\
\hline $\begin{array}{l}\text { The government should nudge us in } \\
\text { the right direction }\end{array}$ & 0 & 1 & 5 & Positive \\
\hline $\begin{array}{l}\text { Government regulation is important } \\
\text { in residential energy use }\end{array}$ & 1 & 0 & 5 & Positive \\
\hline Population and energy is a problem & 0 & 1 & 5 & Positive \\
\hline $\begin{array}{c}\text { Financial situation is the driver } \\
\text { behind energy use }\end{array}$ & 0 & 0 & 6 & Positive \\
\hline $\begin{array}{l}\text { How would you feel about being } \\
\text { given a personal carbon allowance }\end{array}$ & 3 & 0 & 3 & Uncertain \\
\hline Paying a carbon tax & 2 & 1 & 3 & Uncertain \\
\hline
\end{tabular}

The impact of culture on energy use was more positive in Australia than in the UK. One could argue that this may be because there is a stronger status quo bias in the UK due to its rich and ancient history. Australia in contrast is a younger country subjected to cultural influences from antipodean countries in Europe and North America as well as South East Asia. This positive outlook did not go as far as endorsing very far reaching cultural change. There was no suggestion by either participants in the UK or Australia that they would be predisposed to adopt a living systems based approach, where people live in as self sufficient a way as possible, growing part of their food and disposing of much of their own waste. as postulated by Reed [23] and Vale \& Vale [24]. Even Sue (Aus), who was building her own off grid dwelling, was still planning to spend a number of months of each year living in a normal house in the USA (her husband was American). Nevertheless, in both the UK and Australia there were mixed views on how education could influence culture. Some participants felt that education designed to affect energy behaviour had differential effects amongst different groups. For example, wealthy people might be more inclined to satisfy their en- 
ergy needs because they could easily afford to, as there were few obvious negative effects in the short term. Other participants believed that education had a role to play in influencing culture, but that it would be a very slow acting remedy.

Again in both countries there were mixed views on the value of more information regarding domestic energy use. Both smart meters and differential tariffs were seen as useful, but not necessarily very effective. Isacsson et al. [25] argue that total knowledge of all energy related activity is necessary to encourage more efficient energy use, but for those participants such as Arabella (UK) and Angela (AUS) that were sceptical, a similar argument was put forward, which was that some people don't have a choice as to when their energy demands need to be met.

Participants in the UK and Australia were strongly of the opinion that people did not always behave rationally with regard to their energy use. They were also strongly of the opinion that government was the best agency to both regulate energy use and influence energy use behaviour.

The effects of a vast world population in the future was considered by Australian participants to be more likely to have a negative impact on energy use (i.e. increase the use of fossil fuels, thus affecting climate change) than research participants in the UK. One interpretation of this may be that Australia is a very developed country with a very small population and an enormous land mass. The possibility of uncontrolled migration in the future could effectively mean that native Australians could become helpless with regard to managing a sustainable energy policy.

When it came to the effect of finance on energy use, most participants in both countries were clear that it was an important driver behind their energy use. However, participants in both countries had mixed views on a carbon allowance or a carbon tax. This reflected a general distaste for taxation amongst most of the participants. When they stated that they might accept some form of taxation, it was contingent on them being very clear as to how the tax might be used. The implication was that hypothecated taxation would be more acceptable.

\subsection{How Does the Australian Research Inform UK Energy Policy}

A point worth noting is that domestic energy in Australia is required for both heating and cooling, whereas in the UK the requirement is largely for space heating. However, in Victoria state (particularly in Melbourne, where most of the research was carried out) most of the domestic energy requirement is for heating. This was confirmed by Bruce during his interview. "Yes, so P d say $90 \%$ heating. So we've got an in-duct heating system so when it heats up, it heats up all the house".

Nevertheless, Australian energy policy can be said to be a success in terms of encouraging sustainable energy use. Mountain \& Szuster [26] explain that Australia has the highest market penetration for domestic solar panels of any coun- 
try in the world and that this was achieved by offering significant subsidies. This compares well with the UK Green Deal, which unsuccessfully targeted energy efficiency, as distinct from energy sustainability.

While the climate in Australia may favour solar power, the climate in the UK lends itself quite well towards the development of wind power. Given the similarity in attitudes between UK and Australian research participants, it may be that significant subsidies to encourage community wind farms on the outskirts of towns and villages, could form the basis of a successful UK domestic energy strategy.

\section{Conclusions}

It was interesting to note that despite very different energy regimes, common ground was found across most domestic research participants in factors that they thought would motivate them to alter their energy demand behaviour. These included financial incentives, government "nudge" to alter heuristic behaviour and government regulation. Where financial incentives could be effective in encouraging the development of sustainable solar power in Australia, this common ground could mean that along with other strategies, significant levels of financial subsidy could be effective in developing sustainable community wind power in the UK.

This research wanted to understand more clearly what would motivate residential energy users to use more sustainable forms of energy. This is against a background of a lack of clarity around occupancy behaviour with regard to energy use. Previous research tended to concentrate on one aspect that could influence residential energy behaviour. Attribution ranged from financial incentives (such as the UK Green Deal), poor cognitive choices [9], sub optimal decision-making [16], lifestyle choice [24], and the failure to include the cost of externalities in the fuel source [27].

Both in the UK and Australian research, participants agreed that people do not always behave rationally (it is a reasonable, rational assumption to expect that people's attitudes influence their behaviour). This insight is important as it makes energy policy more complex.

Another important piece of knowledge with regard to both countries is that financial incentives can be very important. While this may seem obvious, what has transpired from this research is that financial incentives need to be quite large to be effective. They also need to be tailored to the individual, or at least to a group of individuals. Disparities in wealth will lead to some extent to disparities in motivation.

Despite the very different energy regimes in the UK and Australia, it was interesting to note that energy consumption per capita was similar in both countries. There were also similarities in mixed viewpoints. Participants were uncertain as to the value of better information with regard to their domestic energy use (i.e. the availability of smart meters and differential tariffs). Because the study was undertaken in two concentrated areas, the East Midlands in the UK 
and Melbourne in Australia, no statistical inference can be drawn from it. However the argument can be made for both countries that the findings are of interest, as the culture in other areas of each country is not manifestly different.

With regard to policy, both respondents in Australia and the UK were generally unwilling to undergo any far reaching cultural change, such as adopting a living systems-based approach. Indeed, the idea of government taking responsibility for more efficient energy use rather than the individual resonated well with both sets of participants. This included accepting government regulation as well as being "nudged" in the right direction.

\section{Acknowledgements}

This research was made possible by EPSRC support for the London-Loughborough Centre for Doctoral Research in Energy Demand, Grant Number EP/H009612/1.

\section{Conflicts of Interest}

The authors declare no conflicts of interest regarding the publication of this paper.

\section{References}

[1] DECC (2014) Digest of United Kingdom Energy Statistics (DUKES). Department of Energy and Climate Change. [Online]

https://www.gov.uk/government/statistics/renewable-sources-of-energy-chapter-6digest-of-united-kingdom-energy-statistics-dukes

[2] DCCEE (2012) Australia's Emissions Projections 2012. Department of Climate Change and Energy Efficiency 2012, DCCEE, Canberra, ACT.

[3] Stern, N. (2006) Stern Review on the Economics of Climate Change (Pre-Publication Edition). Executive Summary. HM Treasury, London.

[4] Sandeman, R.J. (2006) A Critique of Present Australian Energy Policy. International Journal of Environmental Studies, 63, 719-729. https://doi.org/10.1080/00207230601073715

[5] Department of the Environment (2014). [Online] http://www.environment.gov.au/

[6] IRENA (2015) Renewable Power Generation Costs in 2014. International Renewable Energy Agency. [Online] http://www.irena.org/publications

[7] Indymedia (2010) [Online] http://www.indymedia.org.au/2010/07/21/victoria-targets-solar-energy-as-new-rep ort-shows-renewable-energy-potential

[8] Wilson, C. and Dowlatabadi, H. (2007) Models of Decision Making and Residential Energy Use. Annual Review of Environment and Resources, 32, 169-203. [Online] https://www.annualreviews.org/doi/abs/10.1146/annurev.energy.32.053006.141137 https://doi.org/10.1146/annurev.energy.32.053006.141137

[9] Thaler, R. (1994) Quasi Rational Economics. Russell Sage Foundation, New York.

[10] Thaler, R. and Sunstein, C. (2009) Nudge: Improving Decisions about Health, Wealth, and Happiness. Penguin, New York.

[11] Kahneman, D. and Tversky, A. (1979) Prospect Theory: An Analysis of Decision under Risk. Econometric, 47, 263-291. https://doi.org/10.2307/1914185

[12] Akerlof, G. and Kranton, R. (2010) Identity Economics: How Our Identities Shape 
Our Work, Wages, and Well-Being. Princeton University Press, Princeton, New Jersey. https://doi.org/10.1515/9781400834181

[13] Akerlof, G. and Kranton, R. (2000) Economics and Identity. The Quarterly Journal of Economics, 115, 715-753. https://doi.org/10.1162/003355300554881

[14] Akerlof, G. and Shiller, R. (2009) Animal Spirits: How Human Psychology Drives the Economy, and Why It Matters for Global Capitalism. Princeton University Press, Princeton, New Jersey.

[15] Keynes, J.M. (1936) The General Theory of Employment, Interest and Money. Macmillan, London, 161-162.

[16] Kahneman, D. (2011) Thinking, Fast and Slow. Macmillan, London.

[17] Bryman, A. (2008) Social Research Methods. 3th Edition, Oxford University Press, Oxford, New York.

[18] Hallin, S. (2016) Reducing Residential Sector Dependence on Fossil Fuels: A Study of Motivating Factors. http://ethos.bl.uk/OrderDetails.do?uin=uk.bl.ethos.689532

[19] BREE (2012) Australian Household Energy Consumption 2000-01-2010-11, Australian Energy Statistics Data-Table F.

http://www.abs.gov.au/AUSSTATS/abs@.nsf/Lookup/4102.0Main+Features10Sep+ $\underline{2012}$

[20] DECC (2015) Domestic Energy Consumption in the UK between 1970 and 2014. Department of Energy and Climate Change.

http://webarchive.nationalarchives.gov.uk/20160512203030/https://www.gov.uk/go vern-

ment/uploads/system/uploads/attachment_data/file/449134/ECUK_Chapter_3_-_D omestic_factsheet.pdf

[21] WPR (2015) Australian Census 2011. http://worldpopulationreview.com/countries

[22] Byrnes, L., Brown, C., Foster, J. and Wagner, L. (2013) Australian Renewable Energy Policy: Barriers and Challenges. Renewable Energy, 60, 711-721. https://doi.org/10.1016/j.renene.2013.06.024

[23] Reed, B. (2007) Shifting from "Sustainability" to Regeneration. Building Research \& Information, 35, 674-680.

http://www.tandfonline.com/doi/abs/10.1080/09613210701475753

[24] Vale, B. and Vale, R. (2010) Domestic Energy Use, Lifestyles and POE: Past Lessons for Current Problems. Building Research \& Information, 38, 578-588. http://www.tandfonline.com/doi/abs/10.1080/09613218.2010.481438

[25] Isacsson, M., et al. (2006) Changing How People Think about Energy. ACEEE Summer Study on Energy Efficiency in Buildings.

http://www.aceee.org/proceedings

[26] Mountain, B. and Szuster, P. (2014) Australia's Million Solar Roofs: Disruption on the Fringes or the Beginning of a New Order. In: Sioshansi, F.P., Ed., Distributed Generation and Its Implications for the Utility Industry, Academic Press, Cambridge, 75-96. https://doi.org/10.1016/B978-0-12-800240-7.00004-7

[27] Tol, R. (2011) The Social Cost of Carbon. Annual Review of Resource Economics, 3, 419-443. https://doi.org/10.1146/annurev-resource-083110-120028 